\title{
CORRELATION BETWEEN FAT CONSUMPTION, SMOKING HABIT, AND STRESS WITH HYPERTENSION AMONG DRIVERS
}

\author{
Mentari Indah Saputri ${ }^{1 *}$, Lailatul Muniroh ${ }^{2}$, Sobhita Paramita ${ }^{3}$ \\ ${ }^{1}$ Nutrition Study Program, Faculty of Public Health, Universitas Airlangga, Indonesia \\ ${ }^{2}$ Departement of Nutrition, Faculty of Public Health, Universitas Airlangga, Indonesia \\ ${ }^{3}$ Management Division, Leeds University Business School, University of Leeds, United Kingdom \\ *E-mail: mentariindah05@gmail.com
}

\begin{abstract}
Hypertension is one of major health problem that affect many people. Driver is one of the jobs that could cause hypertension due to the surrounding environment which support unhealthy lifestyles such as consuming excessive fat, smoking habit and susceptible to stress. The purpose of this research was to analyze the correlation between fat consumption, smoking habit, and stress with hypertension among drivers. This research was an observational study using cross sectional design. The samples were 74 male drivers taken by accidental sampling. The respondent was chosen around Juanda Airport Sidoarjo. The data were collected by measuring blood pressure using digital sphygmomanometer and interview using questionnaire, Semi Quantitative Food Frequency Questionnaire, and The Workplace Stress Scale. The data then analyzed using Pearson and Spearman Correlation test. The results of this research showed that stress $(\mathrm{P}=0,000 ; \mathrm{r}=0,830)$ had strongest correlation with hypertension among drivers compared to two other variables, fat consumption $(\mathrm{P}=0,000 ; \mathrm{r}=0,689)$ and smoking habits $(\mathrm{P}=0,004 ; \mathrm{r}=0,331)$. This study concludes that excessive fat consumption, smoking habit 11-20 cigarettes/day, moderate and severe stress levels can increase the risk of hypertension among drivers. Drivers should adjust to reduce consumption of fried foods, smoking habit, and stress with sufficient rest \pm 7-8 hours/day to prevent the occurrence of hypertension among drivers.
\end{abstract}

Keywords: hypertension, driver, fat consumption, smoking habits, stress.

\section{INTRODUCTION}

Non-Communicable Diseases (NCD) is a leading cause of death that occurs throughout the world. World Health Organization (WHO) 2017 reported total death in 2016 was 56.9 million in which 40.5 million or $71 \%$ of the total number of deaths were due to non-communicable diseases. Indonesia is a country that has an increase in NCD's prevalence including hypertension. Based on the results of the 2013 national survey data, the prevalence of hypertension was $25.8 \%$. (Indonesia $\mathrm{MoH}, 2013)$.

Hypertension is a health problem that occurs in all groups of people, especially workers (Setyani and Nuraini, 2014). Type of work, workload, work environment, lifestyle, and worker characteristics are risk factors for hypertension in workers (Hardati and Ahmad, 2017). One job that has a risk of developing hypertension is the driver (Erhiano et al., 2015). Hypertension among driver can be caused by the work type that mostly sitting, work environment that is prone to stress and possess to unhealthy lifestyle (Ngateni, 2009).

Research conducted by Nasri and Moazenzadeh (2006) on drivers and non-drivers in Kerman, Iran shows that drivers both bus and taxi drivers have a higher risk of developing hypertension compared to non-drivers or other occupations. Erhiano et al. (2015) also proved that the incidence of hypertension in bus drivers in Nigeria was quite high (33.5\%). Swestyastasari (2010) also showed that the incidence of hypertension in bus drivers in Purabaya Terminal, Surabaya was $52.4 \%$. Most bus drivers consume excess fat and experience stress due to working hours $>40$ hours per week so they tend to experience hypertension. Research conducted by Faridah (2017) also revealed that most bus drivers who are smokers $\geq 12$ cigarettes/day tend to have hypertension.

Consumption of excess fat, especially saturated fat can increase Low Density Lipoprotein 
(LDL) cholesterol levels in the body (Wiardani et al., 2011). Fat in the blood, especially LDL cholesterol, has the potential to react with free radicals and cause oxidative stress. In addition, smoking and stress are also exposure to free radicals that trigger oxidative stress (Widayati, 2012). The occurrence of oxidative stress in the body will cause LDL to oxidize and form plaque in blood vessels (Simanjuntak, 2011). The plaque will cause narrowing of the arteries and increase blood pressure (Samuel, 2007). In addition, the nicotine and monoxide content in cigarettes can also cause narrowing of blood vessels then increase blood pressure as well (Faridah, 2017).

Based on previously mentioned studies, it is known that drivers are vulnerable to the risk of developing hypertension. Therefore, this study aims to analyze the relationship between fat consumption, smoking habits and stress level with the incidence of hypertension in the driver.

\section{METHODS}

This was an observational research with cross sectional design. The study population was all drivers around the Juanda Airport area in Sidoarjo, Indonesia. Total sample was 74 male drivers which was collected using non-probability, accidental sampling technique.

The independent variables were fat consumption, smoking habits, and stress while the dependent variable was hypertension. Data collected were blood pressure measurements using a digital sphygmomanometer by a nurse, while interviews were done for other data collection. Fat consumption was collected using the SemiQuantitative Food Frequency Questionnaire (SQFFQ) (Ranuwirna, 2017), stress level using The Workplace Stress Scale (The Marlin Company, 2001), characteristics of respondents (age and family history of hypertension) and smoking habits using a structured questionnaire.

The incidence of hypertension was classified according to the American Hypertension Association (AHA) i.e., normal $(<120 \mathrm{mmHg}$ and $<80 \mathrm{mmHg}$ ), pre-hypertension $(120-129 \mathrm{mmHg}$ and $<80 \mathrm{mmHg}$ ), Hypertension I (130-139 $\mathrm{mmHg}$ or $<90 \mathrm{mmHg}$ ), and Hypertension II ( $\geq 140 \mathrm{mmHg}$ or $\geq 90 \mathrm{mmHg}$ ) (AHA, 2017). Fat consumption was assessed based on the percentage of the level of adequacy of fat consumption compared to the Indonesian Recommended Dietary Allowance (RDA). The percentage results were classified according to WNPG in 2004 which is "less" if it meets $<80 \%$ RDA, "sufficient" if it meets 80 $110 \%$ RDA and "excess" if it meets $>110 \%$ RDA. The smoking habit of the driver was assessed based on the number of cigarettes smoked in a day, then classified into: not smoking, 1-10 cigarettes/ day, 11-20 cigarettes/day, and $>20$ cigarettes/day. The stress level on the driver was assessed based on The Workplace Stress Scale with no stress classification (score $<15$ ), mild stress (score 1620 ), moderate stress (score 21-25), and severe stress (score 26-30).

Data analysis was adjusted with the accidental sampling which includes non-probability technique so it can only analyze the strength of the relationship. Data analysis used was the Pearson and Spearman correlation test. This study has passed the ethical review by the Health Research Ethics Committee of the Faculty of Public Health, Universitas Airlangga (No: 443-KEPK).

\section{RESULT AND DISCUSSION}

Respondent characteristics (age and family history of hypertension), fat consumption, smoking habits, stress and the incidence of hypertension among drivers in this study can be seen in Table 1 .

\section{Characteristics of Respondents}

The age of the drivers in this study are grouped according to the adult age group in the Indonesian RDA. This was because there was fat intake variable that compared to the RDA according to age group. Based on Table 1, the majority of drivers aged 30-49 years (78.4\%), with an average age of 41-42 years. According to BPS (2014), ages 15-64 years included as productive age so that all drivers are in productive age and able to work as a driver.

In addition, the majority of respondents $(77.0 \%)$ did not have a family history of hypertension and the rest $23.0 \%$ had a family history of hypertension from one parent. This is consistent with Rizkawati's study (2012) that most TransJakarta bus drivers do not have a family 
Table 1. Frequency Distribution of Respondent Characteristics, Fat Consumption, Smoking Habits, Stress, Hypertension in Drivers

\begin{tabular}{lcc}
\hline \multicolumn{1}{c}{ Variable } & n & $\mathbf{( \% )}$ \\
\hline Age & & \\
30-49 years & 58 & 78.4 \\
50-64 years & 16 & 21.6 \\
Family history of hypertension & & \\
$\quad$ Present & 17 & 23 \\
$\quad$ Not present & 57 & 77 \\
Fat intake & & \\
Deficit & 0 & 0.0 \\
Sufficient & 46 & 62.2 \\
$\quad$ Excess & 28 & 37.8 \\
Smoking habits & & \\
$\quad$ Not smoking & 15 & 20.3 \\
1-10 cigarettes/day & 15 & 20.3 \\
11-20 cigarettes/day & 41 & 55.4 \\
>20 cigarettes/day & 3 & 4.1 \\
Stress & & \\
$\quad$ Not stress & 4 & 5.4 \\
Mild stress & 33 & 44.6 \\
Moderate stress & 35 & 47.3 \\
$\quad$ Severe stress & 2 & 2.7 \\
Hypertension & & \\
Normal & 14 & 18.9 \\
Pre-hypertension & 26 & 35.1 \\
Hypertension I & 25 & 33.8 \\
Hypertension II & 9 & 12.2 \\
\hline
\end{tabular}

history of hypertension (79.3\%) and drivers who have a family history of hypertension are mostly owned by one of the driver's parents.

\section{Hypertension}

Based on Table 1, almost half of the drivers had hypertension (46.0\%), 33.8\% was hypertension
I and $12.2 \%$ was hypertension II. This is consistent with Faridah's study (2017) that most InterProvincial/Inter-city bus drivers do not experience hypertension. However, the prevalence of hypertension in the driver in this study was greater than the national prevalence of hypertension based on the 2013 national health survey which revealed only $25.8 \%$ adults with hypertension. Hypertension experienced by a driver can be caused by several factors, including fat consumption, smoking habits and stress (Ngateni, 2009; Swestyastasari, 2010).

\section{Fat Intake}

Based on Table 1, there was no driver with less consumption of fat. The majority of fat intake among driver $(62.2 \%)$ was sufficient with an average of $105.6 \%$ RDA of fat.

Sufficient intake of fat might be due to drivers' eating habit who consume fried foods mostly every day $(81.1 \%)$. The most fried foods consumed by the driver were tofu, tempeh, eggs and fish. In addition, the driver also consumes food sources of fat in the weekly basis i.e. chicken $(79.9 \%)$, beef $(71.6 \%)$ and meatballs $(68.9 \%)$. The frequency of food types consumed by the driver showed in Table 2.

Our result is in line with Swestyastasari's study (2010) which shows that almost all city bus drivers consume cooking oil contained in every day food. Fried foods have more delicious and savory taste compared to foods that are boiled and steamed causes majority of people process food by frying that is dependent on cooking oil (Amalia et

Table 2. Frequency of Fat Food Source Intake among Drivers

\begin{tabular}{lcccccccccc}
\hline \multirow{2}{*}{ Fat food source } & \multicolumn{2}{c}{ Daily } & \multicolumn{2}{c}{ Weekly } & \multicolumn{2}{c}{ Monthly } & \multicolumn{2}{c}{ Never } & \multicolumn{2}{c}{ Total } \\
\cline { 2 - 12 } & $\mathbf{n}$ & $\mathbf{( \% )}$ & $\mathbf{n}$ & $\mathbf{( \% )}$ & $\mathbf{n}$ & $\mathbf{( \% )}$ & $\mathbf{n}$ & $\mathbf{( \% )}$ & $\mathbf{n}$ & $\mathbf{( \% )}$ \\
\hline Eggs & 15 & 20.3 & 49 & 66.2 & 10 & 13.5 & 0 & 0 & 74 & 100 \\
Chicken & 1 & 1.4 & 59 & 79.7 & 14 & 18.9 & 0 & 0 & 74 & 100 \\
Beef & 1 & 1.4 & 53 & 71.6 & 17 & 23 & 3 & 4.1 & 74 & 100 \\
Lamb & 0 & 0 & 6 & 8.1 & 51 & 68.9 & 17 & 23 & 74 & 100 \\
Duck & 0 & 0 & 14 & 18.9 & 44 & 59.5 & 16 & 21.6 & 74 & 100 \\
Beef tripe/organs & 0 & 0 & 12 & 16.2 & 27 & 36.5 & 35 & 47.3 & 74 & 100 \\
Meatballs & 0 & 0 & 51 & 68.9 & 18 & 24.3 & 5 & 6.8 & 74 & 100 \\
Sausage & 3 & 4.1 & 2 & 2.7 & 20 & 27 & 49 & 66.2 & 74 & 100 \\
Full cream milk & 5 & 6.8 & 29 & 39.2 & 22 & 29.7 & 18 & 24.3 & 74 & 100 \\
Cheese & 0 & 0 & 4 & 5.4 & 12 & 16.2 & 58 & 78.4 & 74 & 100 \\
Fried foods & 60 & 81.1 & 14 & 18.9 & 0 & 0 & 0 & 0 & 74 & 100 \\
\hline
\end{tabular}


al., 2010). Cooking oil that is often used is palm oil which contains saturated fatty acids by $51 \%$ and unsaturated fatty acids by $49 \%$ (Hanum, 2016). The more often the cooking oil is used, the more saturated fatty acids contained in the cooking oil (Yusuf et al., 2013).

Based on Table 3, the majority of drivers who consume excess fat tend to experience hypertension, while the consumption of sufficient fat tends to not experience hypertension. Statistical test using Pearson correlation test showed P-value $=0,000$ with $\mathrm{r}=0.689$ which means there was a strong relationship between fat consumption with the incidence of hypertension in the driver. A possible explanation is that the more consumption of fat, especially saturated fat, will increase Low Density Lipoprotein (LDL) cholesterol levels (Yusuf et al., 2013). Increasing LDL cholesterol can trigger faster reactions with free radicals and cause oxidative stress. The occurrence of oxidative stress in the body due to high ROS (Reactive Oxygen Species) and low antioxidants causes oxidized LDL. LDL oxidation then increase the plaque formation on blood vessel walls (Simanjuntak, 2011). Plaque that forms will accumulate and cause narrowing of blood vessels so that blood pressure increases (Samuel, 2007).

The results of this study are in accordance with Swestyastasari research (2010) showing that there was a relationship between fat consumption and the incidence of hypertension in bus drivers, in which drivers who consume excess fat will be 17.66 times more at risk of developing hypertension compared to those who consumption sufficient fat. Thus, high consumption of fat could increase the risk of hypertension in the driver.

\section{Smoking Habit}

The risk of hypertension in smokers does not depend on the length of smoking, but the number of cigarettes smoked in a day (Muttaqin, 2009). Based on Table 1, the majority of drivers smoke as many as 11-20 cigarettes/day (55.4\%). The highest number of cigarettes smoked by the driver was 32 cigarettes/day. This is consistent with Swestyastasari's research (2010) that most city bus drivers smoke as many as 10-20 cigarettes/day.

Based on Table 3, the majority of drivers who smoke 11-20 cigarettes/day tend to have hypertension compared to drivers who don't smoke. Statistical test using the Spearman correlation test showed $\mathrm{P}$-value $=0.004$ with $\mathrm{r}=0.331$ which means there was a weak relationship between smoking and the incidence of hypertension among driver. The relationship between smoking and hypertension was due to the nicotine content in cigarettes that stimulate sympathetic nerves resulting in narrowing of blood vessels. Moreover, carbon monoxide in cigarettes can replace oxygen in the blood so that it triggers the heart to work harder then will increases blood pressure (Faridah, 2017). Cigarette smoke is exposure to free radicals originating from external sources that can increase Reactive Oxygen Species (ROS) in the body and cause oxidative stress and oxidation of cholesterol Low Density Lipoprotein (LDL). Oxidized LDL results in the formation of plaque and triggers narrowing of blood vessels resulting elevation in blood pressure (Fitria et al., 2013).

The results of this study was in line with Faridah's research (2017) that explained a relationship between smoking habits and the incidence of hypertension in inter-city/interprovincial bus drivers $(A K A P)$. AKAP bus drivers who experience hypertension tend to consume as much as $\geq 12$ cigarettes/day and have 3,816 times hinger risk compared to drivers who are not smokers and drivers who smoke 1-11 cigarettes/ day. Thus, we conclude that the more cigarettes smoked, the higher risk of hypertension will occur.

\section{Stress Level}

Stress level in our study was assessed based on the total score (Table 1). The majority of drivers experienced a moderate stress level (47.3\%). The stress experienced by the driver was mostly caused by working in excess reasonable time limit or more than 8 hours a day. Most drivers work 9-12 hours a day and 5 days in a week. This was in line with Swestyastasari's study (2010) that most city bus drivers experience stress due to high working more than 40 hours a week.

Furthermore, based on Table 3, the majority of drivers who had severe and moderate stress tend to experience hypertension compared to drivers who had mild or not experiencing stress. Statistical test using the Pearson correlation test showed Pvalue 
Table 3. The Relationship between Fat Consumption, Smoking Habits, Stress with Hypertension in Drivers at Juanda Airport, Surabaya, Indonesia

\begin{tabular}{|c|c|c|c|c|c|c|c|c|c|c|c|c|}
\hline \multirow{3}{*}{ Variable } & \multicolumn{8}{|c|}{ Hypertension } & & & \multirow{3}{*}{$\mathbf{P}$} & \multirow{3}{*}{$r$} \\
\hline & \multicolumn{2}{|c|}{ Normal } & \multicolumn{2}{|c|}{$\begin{array}{c}\text { Pre } \\
\text { Hyperten- } \\
\text { sion } \\
\end{array}$} & \multicolumn{2}{|c|}{ Hypertension I } & \multicolumn{2}{|c|}{$\begin{array}{c}\text { Hypertension } \\
\text { II }\end{array}$} & \multicolumn{2}{|c|}{ Total } & & \\
\hline & n & $(\%)$ & $\mathbf{n}$ & $(\%)$ & n & $(\%)$ & n & $(\%)$ & $\mathbf{n}$ & $(\%)$ & & \\
\hline \multicolumn{13}{|l|}{ Fat intake } \\
\hline Sufficient & 14 & 30.4 & 22 & 47.8 & 8 & 17.4 & 2 & 4.3 & 46 & 100.0 & 0.000 & 0.689 \\
\hline Excess & 0 & 0.0 & 4 & 14.3 & 17 & 60.7 & 9 & 25.0 & 28 & 100.0 & & \\
\hline \multicolumn{13}{|l|}{ Smoking habit } \\
\hline Not smoking & 5 & 33.3 & 6 & 40.0 & 3 & 20.0 & 1 & 6.7 & 15 & 100.0 & & \\
\hline $1-10$ cigarettes/day & 7 & 46.7 & 3 & 20.0 & 4 & 26.7 & 1 & 6.7 & 15 & 100.0 & 0.004 & 0.331 \\
\hline $11-20$ cigarettes/day & 2 & 4.9 & 15 & 36.6 & 17 & 41.5 & 7 & 17.1 & 41 & 100.0 & & \\
\hline$>20$ cigarettes/day & 0 & 0.0 & 2 & 66.7 & 1 & 33.3 & 0 & 0.0 & 3 & 100.0 & & \\
\hline \multicolumn{13}{|l|}{ Stress } \\
\hline Not stress & 4 & 100.0 & 0 & 0.0 & 0 & 0.0 & 0 & 0.0 & 4 & 100.0 & & \\
\hline Mild stress & 10 & 30.3 & 23 & 69.7 & 0 & 0.0 & 0 & 0.0 & 33 & 100.0 & 0.000 & 0.830 \\
\hline Moderate stress & 0 & 0.0 & 3 & 8.6 & 24 & 68.6 & 8 & 22.9 & 35 & 100.0 & & \\
\hline Severe stress & 0 & 0.0 & 0 & 0.0 & 1 & 50.0 & 1 & 50.0 & 2 & 100.0 & & \\
\hline
\end{tabular}

$=0,000$ with $\mathrm{r}=0.830$ which means there was a strong relationship between stress level and the incidence of hypertension among driver. A possible mechanism is because severe stress stimulates the sympathetic nervous system which cause arteriolar constriction resulting changes in blood pressure in short term (Sani, 2008). Stress also triggers an increase in Reactive Oxygen Species (ROS) associated with plaque formation (Widayati, 2012). The plaque will cause narrowing of the arteries and increase blood pressure (Samuel, 2007). Stress also triggers the production of the hormone adrenaline which will increase cardiac output thereby causing an increase in blood pressure (Tilong, 2014).

Our study is in accordance with Rizkawati's research (2012) showing that the incidence of hypertension is higher in bus drivers who experience moderate stress levels compared to bus drivers who experience mild stress levels. Thus, the heavier the stress level experienced by the driver will increase the risk of hypertension.

\section{CONCLUSION}

Our study concludes that nearly half (46\%) of the drivers had hypertension. Excessive fat consumption, smoking habits 11-20 cigarettes/day and stress due to $>8$ hours working time in a day will increase the risk of hypertension among driver. Excessive fat consumption, smoking habits and stress trigger an increase in free radicals and react with LDL cholesterol in the body which causes oxidative stress. The occurrence of oxidative stress results in LDL oxidation which triggers plaque formation and constriction of blood vessels until it increases blood pressure. The driver should begin to change behavior by reducing the consumption of fried foods, reducing smoking, and reducing stress with enough rest $\pm 7-8$ hours/day to prevent hypertension.

\section{REFERENCES}

American Heart Association. (2017). Detailed summary from the guideline for the prevention, detection, evaluation and management of high blood pressure in adults. Retrieved from https://healthmetrics.heart.org/wp-content/ uploads/2017/11/Detailed-Summary.pdf

Amalia, F., Retnaningsih, \& Johan, I. R. Y. (2010). Perilaku penggunaan minyak goreng serta pengaruhnya terhadap keikutsertaan program pengumpulan minyak jelantah di Kota Bogor. Jurnal Ilmu Keluarga dan Konsumen, 3(2), 184-189. Retrieved from http://journal.ipb.ac.id/ index.php/jikk/article/view/5199

BPS. (2014). Statistik pemuda Indonesia. Jakarta: Badan Pusat Statistik.

Erhiano, E. E., Igbokwe, V. U., ElKhashab, M. M., Okolo, R. U., \& Awosan, K. J. (2015). Prevalence of hypertension among commercial bus drivers in Sokoto, Sokoto State Nigeria. 
International Invention Journal of Medicine and Medical Sciences, 2(3), 34-39. Retrieved from http://internationalinventjournals.org/journals/ IIJMMS/Archive/2015/March_vol-2-issue-3/ fulltext/Erhiano\%20et\%20al.pdf

Faridah, D. (2017). Determinan hipertensi pada supir bus akap (antar kota antar provinsi) di terminal wilayah Kota Jakarta Timur tahun 2017. Skripsi. Jakarta: Universitas Islam Negeri Syarif Hidayatullah. Retrieved from http://repository.uinjkt.ac.id/dspace/ handle/123456789/36711

Fitria, R. I. N. K., Triandhini, R., Mangimbulude, J. C., \& Karwur, F. F. (2013). Merokok dan oksidasi DNA. Sains Medika, 5(2), 113-120. Retrieved from http://download.portalgaruda. org/article.php?article $=342357 \& \mathrm{val}=322 \&$ titl $\mathrm{e}=$ Merokok\%20dan\%200ksidasi\%20DNA

Hanum, Y. (2016). Dampak bahaya makanan gorengan bagi jantung. Jurnal Keluarga Sehat Sejahtera, 14(28), 103-114. Retrieved from https://jurnal.unimed.ac.id/2012/index.php/jkss/ article/download/4700/4131

Hardati, A. T. \& Ahmad, R. A. (2017). Aktivitas fisik dan kejadian hipertensi pada pekerja: analisis data Riskesdas 2013. Berita Kedokteran Masyarakat, 33(10), 467-474. Retrieved from https://media.neliti.com/ media/publications/237978-aktivitas-fisik-dankejadian-hipertensi-fece1be1.pdf

Kemenkes RI. (2013). Laporan hasil riset kesehatan dasar Indonesia tahun 2013. Jakarta: Badan Penelitian dan Pengembangan Kesehatan Kementerian Kesehatan Republik Indonesia.

Muttaqin, A. (2009). Pengantar asuhan keperawatan dengan gangguan sistem kardiovaskular. Jakarta: Salemba Medika.

Nasri, H., \& Moazenzadeh, M. (2006). Coronary artery diseases risk factors in drivers versus people in other occupations. ARYA Journal, 2(2), 75-78. Retrieved from https://pdfs. semanticscholar.org/1960/1195afd447fca99d5 a31f7c1ab8c5e56b241.pdf

Ngateni. (2009). Hubungan kebiasaan minum kopi, merokok, olahraga, dan stress dengan kejadian hipertensi pada sopir bemo di Terminal Joyoboyo Surabaya. (thesis). Universitas Airlangga, Surabaya.

Rizkawati, D. (2012). Indeks massa tubuh, lama bekerja, kebiasaan makan, dan gaya hidup hubungannya dengan hipertensi pada pramudi (pengemudi) Bus Transjakarta Tahun 2012. Skripsi. Jakarta: Universitas Indonesia. Retrieved from http://lib.ui.ac.id/ file?file=digital/20321150-S-PDF-Destry $\% 20$ Rizkawati.pdf.

Samuel, F. (2007). Smart treatment for high blood pressure. Jakarta: PT Prestasi Pustaka Raya.

Sani, A. (2008). Hypertension current perspective. Jakarta: Medya Crea.

Setyani, K. A. \& Nuraini, T. (2014). Gaya hidup dan kejadian hipertensi pada pekerja. Naskah Publikasi. Jakarta: Universitas Indonesia. Retrieved from http://lib.ui.ac.id/ naskahringkas/2015-08/S46505-Kartika\%20 Ayu\%20Setyani

Swestyastasari, R. (2010). Hubungan tingkat konsumsi lemak, status gizi, dan stress dengan kejadian hipertensi pada sopir bus kota (studi kasus di Terminal Purabaya Surabaya). (Skripsi tidak dipublikasikan). Univeristas Airlangga, Surabaya.

The Marlin Company. (2001). Attitudes in the American Workplace VII. North Haven, Conn: The Marlin Company. Retrieved from https://www.stress.org/wp-content/ uploads/2011/08/2001 Attitude-in-theWorkplace-Harris.pdf

Tilong. D. A. (2014). Waspada penyakit-penyakit mematikan tanpa gejala menyolok. Yogyakarta: Buku Bir.

Widayati, E. (2012). Oxidasi biologi, radikal bebas, dan antioxidant. Majalah Ilmiah Sultan Agung, 50(128), 26-32. Retrieved from http://jurnal.unissula.ac.id/index. $\mathrm{php/majalahilmiahsultanagung/article/}$ viewFile/70/64

Wiardani, N. K., Sugiani, P. P., \& Gumala, N. M. Y. (2011). Konsumsi lemak total, lemak jenuh, dan kolesterol sebagai faktor risiko sindroma metabolik pada masyarakat perkotaan di Denpasar. Jurnal Gizi Klinik Indonesia, 7(3), 121-128. Retrieved from https://jurnal.ugm. ac.id/jgki/article/view/17751/11521

WHO. (2017). Global Health Observatory Data: NCD mortality and morbidity. Geneva: World Health Organization. Retrieved from http:// www.who.int/gho/ncd/mortality_morbidity/ en/

WNPG. (2004). Ketahanan pangan dan gizi di era otonomi daerah dan globalisasi. Widyakarya Nasional Pangan dan Gizi Jakarta: Lembaga Ilmu Pengetahuan Indonesia. 
Yusuf, F., Sirajuddin, S., \& Najanuddin, U. (2013). Analisis kadar asam lemak jenuh dalam gorengan dan minyak bekas hasil penggorengan makanan jajanan di lingkungan workshop
Universitas Hasanuddin. Naskah Publikasi. Makassar: Universitas Hasanuddin. Retrieved from http://repository.unhas.ac.id/bitstream/ handle/123456789/5503/JURNAL.pdf 